\title{
"We're just all human, ya know?" Comparing the Rhetoric of President Donald Trump With the Immigration Stories of Mexican Immigrants
}

\author{
Sarah Andresen ${ }^{1}$
}

${ }^{1}$ Perry Meridian High School, Indianapolis, Indiana, USA

\begin{abstract}
$\underline{\text { ABSTRACT }}$
Immigration has been part of American society for as long as America has been established. Because of the differing opinions and attitudes of immigration, the question arises: how does the rhetoric used in the immigration stories of Mexican immigrants living in the central Indianapolis area reflect rhetoric used under the Trump administration regarding Mexican immigration and the characterization of Mexican immigrants? A mixed-method study consisting of qualitative interviews and content analysis was conducted in order to answer this question. Interviews from Mexican immigrants were analyzed, as well as four 2018 rally speeches by President Donald Trump. The analyses were compared, and it was found that the rhetoric used highly differed in the interviews and speeches, with President Trump's rhetoric being more negative and the immigrants' rhetoric being more positive.
\end{abstract}

\section{Introduction}

"Give me your tired, your poor, Your huddled masses yearning to breathe free, The wretched refuse of your teeming shore. Send these, the homeless, tempest-tossed, to me: I lift my lamp beside the golden door" (Lazarus, 1886). These words, written on the plaque below the Statue of Liberty, reference the idea of America as a safe place for those of all nations. Historically, America has been a place of diversity. Even with this remaining true, in recent history, immigration has been dealt with in many different ways. This includes the national origins quota, which, simply put, established quotas for the number of immigrants allowed from each nation (Office of the Historian, n.d.). It allowed for two percent of the total population of each nationality that was recorded in the 1890 census in the United States, and it excluded those from Asia entirely (Office of the Historian, n.d.). This was one of the first truly restrictive immigration laws in United States history (Office of the Historian, n.d.). While more immigration acts were enacted before 1980, a significant one was the United States Refugee Act of 1980. The act defined the term refugee as one who is unable to go to his or her home country because of a fear of persecution (American Immigration Council, 2019). The definition differs from the definition of an immigrant, which is someone who comes to the United States voluntarily (American Immigration Council, 2019). It also raised the annual ceiling for refugees from 17,400 to 50,000 and created a process to raise the ceiling if need be due to emergencies (National Archives Foundation, 2015). Furthermore, the Office of Refugee Resettlement was created with this act, which served to provide resources for refugees to help with assimilation (Office of Refugee Resettlement, 2019).

Immigration laws in America have mainly been a reflection of the fluctuation of immigrants to the United States. There have been four major waves, all consisting of people from different areas of the world. (Martin, 2014). The first wave of immigration came from Northern and Western Europe in the early 1800s, with the majority coming from England (Martin, 2014). The second wave was in the 1840s and 1850s, as German and Irish Catholics came to escape poverty and persecution (Preceden, n.d.). After this, from 1880-1914, there was an influx of immigrants from Western Europe into Ellis Island in New York looking for jobs, but the quotas implemented in the 1920s started to 
slow this third wave (Martin, 2014). After the third wave and continuing until around the 1960s, there was a lull in immigration (Martin, 2014). After 1965, however, a fourth wave began of mainly Latin American and Asian immigrants (Martin, 2014). The United States is currently in the fourth wave of immigration, with an influx of mostly Mexican immigrants coming into the United States (Preceden, n.d.). There have been many varying attitudes with these waves of immigration, and along with it came varying types of rhetoric used in response to an influx of immigrants.

\section{Literature Review}

Through immigration law and the waves of immigrants, it is easy to see that America has an extensive history of being a place of immigration, going from around 8,300 legal immigrants in 1820 to around 1,000,000 in 2018 (U.S. Department of Homeland Security, 2020). Even with immigration as a seemingly constant presence in America, many negative attitudes have been presented in American society regarding the topic, arising mainly from fear (Kawanabe, 1996). For example, the anti-Chinese movement of the 19th century, in which Chinese stereotypes included "sinister" and "exotic," serves as a representation of the negative, harmful, and racist rhetoric that has been used in the immigration debate (Kawanabe, 1996). This debate, however, has increased in recent times with an increased focus on border security, mostly regarding the Southern border, to prevent immigrants from coming into the United States (Felter \& Renwick, 2019). The rhetoric used in political speeches has been and still is dominated by xenophobia, which is defined as "fear or hatred of strangers or foreigners," creating emotionally charged, possibly nonfactual rhetoric (Merriam Webster, 2020). As previously mentioned, xenophobia has permeated political rhetoric throughout history. This rhetoric, however, only increased with the election of a new president in 2016, and it will be further examined in this study.

When Donald J. Trump was elected president of the United States of America in 2016, an intense immigration debate and inflamed rhetoric began surrounding Mexican immigrants (Fritze, 2019). To research this, a study conducted in 2018 by Erika Sabrina Quiñonez investigated the anti-immigration rhetoric President Trump has used through critical discourse analysis of his speeches and conservative mainstream media (Quiñonez, 2018). In her study, she found words such as "aliens," "invasion," and "illegals" were starting to be used in order to describe Mexican immigrants, contributing to an "us versus them" environment (Quiñonez, 2018). This rhetoric has also highlighted the tendency of Americans to label immigrants as illegal, undeserving, and criminals (Chavez, 2013). Furthermore, this stereotype increases xenophobia, or fear of outsiders, in America and pushes the ambivalence towards hatred (Relman, 2019). The increasingly negative rhetoric used in the current immigration debate contributes to a defined immigration controversy under the Trump administration.

Along with the attitudes of Americans about immigration, there are also differing attitudes of immigrants themselves. A study that highlights this is one conducted by Linda K. Ko and Krista M. Perreira in 2010 on Latin American immigrants. The study collected interview data from Latino youth immigrants and analyzed their perspectives on immigration in relation to their migration and acculturation experiences. The results of the study identified "three phases of the migration journey -- pre-migration, migration, and post-migration" (Ko \& Perreira, 2010). Many risk and resilience factors were also identified, such as separating from parents, living in a harsh economic environment, identifying new opportunities, and looking forward to the good life (Ko \& Perreira, 2010). While this study did aid in identifying the specific struggles and benefits of immigration on Latin American youth immigrants, it does not address specifically Mexican immigrants. It also does not address how the way immigrants describe their experiences compared to how President Donald Trump describes immigrants and immigration.

While there is research about the rhetoric President Trump has used and how the way immigrants describe their experiences, there is little about how these connect or how this rhetoric directly compares to the rhetoric immigrants themselves use. This leads to the question: How does the rhetoric used in the immigration stories of Mexican immigrants living in the central Indianapolis area reflect rhetoric used under the Trump administration regarding Mexican immigration and the characterization of Mexican immigrants? 


\section{Method}

This study will be conducted in Indianapolis, Indiana, and is approved by an institutional review board with modifications. My modifications included revising the planned time for the interviews, focusing on a specific aspect of President Trump's views in order to perform the content analysis on the rally speeches, and adding more specificities to my sampling method. Revising my interview questions and assuring I am using audio recordings and not video recording was also included in the modifications. To begin, I will use a mixed-method approach consisting of a qualitative interview method, which will allow me to obtain detailed, differing stories from several subjects I interview and conduct a content analysis, as previously described, on both the transcribed interviews and four rally speeches of President Donald Trump. I will use the interview data in order to compare the rhetoric used in the immigration stories of Mexican immigrants to the rhetoric used in four of President Trump's 2018 rally speeches.

First, I will begin by analyzing President Trump's speeches with a content analysis method used by Benita J. Barnes, Elizabeth A. Williams, and Shuli Arieh Archer in a 2010 study analyzing doctoral students' perceptions of positive and negative attributes of advisors. The content analysis method is appropriate because it focuses on analyzing specific words. The method consisted of five main steps. The first was reading through the responses gathered in order to "gauge the entirety of their content" (Barnes, Williams, Archer, 2010). The second step consisted of identifying a content category, which is defined as the topic the content being analyzed is about (Barnes, Williams, Archer, 2010). In the case of their study, the content category was advisor attributes, and they flagged all comments that discussed the content category (Barnes, Williams, Archer, 2010). Next, the researchers developed "categories and coding schemes" (Barnes, Williams, Archer, 2010). The fourth step included "reading, categorizing, and coding the tagged responses" (Barnes, Williams, Archer, 2010). The last step becomes creating meaning from the coded data (Barnes, Williams, Archer, 2010). In this particular study, the researchers were searching for specifically positive and negative attributes, since that is what primarily appeared. I will also be searching for positive and negative descriptions because this is primarily the type of descriptions used in both the rally speeches and the interviews. To code for positive and negative rhetoric, I defined positive as characteristics that favor immigrants and negative as characteristics that speak against immigrants. Using this method, I can analyze the rhetoric used towards immigrants and about immigration. This method is appropriate because it focuses on analyzing specific words, which is necessary for both the interviews I will conduct and the speeches from President Trump. I will code for any piece, negative or positive, of immigration discussion that occurs, and the number of immigration-focused words or phrases used in the speeches will be considered the data. I will be focusing on the four rally speeches President Trump delivered in Indiana in 2018. To ensure no bias was involved, I chose these four speeches specifically because the immigrants I will be interviewing live in Indiana. Furthermore, the year is more current than the other rallies President Trump held in Indiana.

Second, I will be working with informants, who are Mexican, in order to gain access to a Mexican community and Mexican immigrants. I will gather interviewees, who are Mexican immigrants, using a convenience sampling method, interviewing immigrants my informants know. The immigrants must be available and willing to participate. The Mexican immigrants will continue to be interviewed, with the goal of reaching as many people as possible. I will stop interviewing when the interview answers start to sound similar regarding the reason the immigrants came to the United States or how they immigrated to the United States. To gather the immigrants' stories, an interview process about their immigration story will be used. The interview consists of the central question: "Tell me your immigration story." and follow up questions, which are "At what age did you first come to the United States of America?", "What year did you come to the United States?", "What words would you use to describe Mexican immigrants?", "What words would you use to describe the process of immigration?," and "Do you believe, ultimately, it was a good decision to come to the United States?" To determine the interview questions, I looked at several websites that gave sample qualitative interview questions. The website I mainly used to formulate the questions was one that included advice from "'Stretching' Exercises for Qualitative Researchers" by Valerie J. Janesick, a professor who teaches classes in qualitative research methods at the University of South Florida. I tailored the questions to pertain to the aim of my 
research by explicitly tying them to immigration, and I decided what questions I would need to ask in order to gain the information I would need to use.

Lastly, after transcribing the interviews, I will code for any emergent themes that reveal the descriptions showing the characterization of immigrants or the process of immigration.

The subjects in my research project will be required to complete an informed consent form detailing benefits and risks in order to participate in the study, and their participation will be entirely voluntary. The interview data I collect from the participants will not include any participant names or citizenship status' and will not be shared with anyone else. I will be referring to the participants using their gender and age. The recordings and transcription data will be immediately disposed of when the study is finished. The participants will not be offered any incentives in order to participate.

\section{Results}

From the coding done on President Trump's rally speeches, several main themes arose that were mainly negative, including borders, crime, immigrants receiving privileges over Americans, ICE, characterization of immigrants, caravans, and drugs, as referenced in Table 1, which was made using the data gathered.

Table 1. Number of positive and negative themes and averages for each theme in each of the four analyzed rally speeches by President Donald Trump

\begin{tabular}{|l|l|l|l|l|l|}
\hline & Elkhart, IN & Evansville, IN & $\begin{array}{l}\text { Indianapolis, } \\
\text { IN }\end{array}$ & Fort Wayne, IN & Averages \\
\hline Borders & 6 & 3 & 7 & 3 & 4.75 \\
\hline Crime & 1 & 6 & 8 & 3 & 4.5 \\
\hline $\begin{array}{l}\text { Immigrants Re- } \\
\text { ceiving Privi- } \\
\text { leges }\end{array}$ & 1 & 2 & 2 & 3 & 2 \\
\hline ICE & 0 & 5 & 1 & 3 & 2.25 \\
\hline $\begin{array}{l}\text { Characteriza- } \\
\text { tion }\end{array}$ & 0 & 4 & 7 & 5 & 4 \\
\hline Caravan & 0 & 0 & 4 & 4 & 2 \\
\hline Drugs & 0 & 0 & 3 & 3 & 1.5 \\
\hline $\begin{array}{l}\text { Merit-Based } \\
\text { Immigration }\end{array}$ & 1 & 0 & 1 & 0 & 0.5 \\
\hline Unemployment & 0 & 1 & 0 & 0 & 0.25 \\
\hline Border Patrol & 0 & 1 & 1 & 1 & 0.75 \\
\hline
\end{tabular}

While there were many themes discussed, shown in Table 1, there were four themes that were heavily present in the four rally speeches analyzed. Table 1 displays the total amount of each theme found in each speech and the averages of each theme. A prevalent theme discussed in the rally speeches was borders. Comments made regarding borders were overwhelmingly about the negative consequences open or weak borders would create and how the border should be secured. Another heavily present theme was crime associated with Mexican immigrants or immigration. Examples of phrases used were "massive amounts of crime," "hardened criminals," "endangering your communities," "criminals, drug dealers, and terrorists," "traffickers," and "break our laws, violate our borders, and overrun our country” (Trump, 2018a; Trump, 2018b; Trump, 2018c; Trump, 2018d). Furthermore, many phrases were used to create a 
primarily negative characterization of immigrants. Examples of such phrases were "scum," "the enemy," "illegal aliens," "violent predators and MS-13 killers," "criminal aliens," and "animals" (Trump, 2018a; Trump, 2018b; Trump, 2018c; Trump, 2018d). In his Evansville, Indiana rally, President Trump used the phrase "getting them the hell out" regarding Mexican immigrants several times within his speeches and said, "And then I call them animals, and Nancy Pelosi gets upset because I'm talking about 'human beings.' They don't get it. They don't get it” (Trump, 2018a). Lastly, immigrants coming to the United States in caravans was also an emergent theme (Trump, 2018c; Trump, 2018d).

Some emergent themes appeared less than borders, crime, characterization, or caravans but were still heavily discussed in the speeches. President Trump often referenced immigrants receiving benefits over Americans, such as welfare and education (Trump, 2018a; Trump, 2018b; Trump, 2018c; Trump, 2018d). Another prevalent theme was ICE, or U.S. Immigration and Customs Enforcement (Trump, 2018b; Trump, 2018c; Trump, 2018d). The phrases used when discussing ICE were mainly portraying ICE workers as "brave people" and "good people" (Trump, 2018a). Continued discussion about ICE was referencing some who want to abolish ICE, which President Trump approached as a negative idea (Trump, 2018a). The last prominent theme was drugs being brought in through the southern border by immigrants and harming American lives (Trump, 2018c; Trump, 2018d).

Among the negative themes, there was one positive that did not appear in the table because it was only mentioned once or twice in total. Merit-based immigration was considered positive, and President Trump mentioned it as a possible solution that could be utilized in America to reduce illegal immigration (Trump, 2018b; Trump, 2018d). President Trump also mentioned in a few of the speeches that immigration is welcome, but only if it is legal immigration (Trump, 2018c; Trump, 2018d). President Trump also discussed unemployment for Hispanic Americans, and he mentioned it was the lowest rate it had ever been in our country (Trump, 2018a). These were the only positive themes in the speeches regarding immigration or immigrants.

While the rhetoric prevalent in the speeches was considered primarily negative, the rhetoric used in the immigrant stories I analyzed was mainly positive. Of the major themes, hardworking and better opportunities were very prevalent. Nine of the thirteen participants used "hardworking" to describe immigrants, and twelve of the thirteen said the main reason they came to the United States was for better opportunities, family, a better life, or stability. The participants also often discussed Mexican immigrants as people who are "traditional families" and are involved in their "customs," as a forty-four-year-old female participant said. Many of the participants also mentioned, as a sixtyone-year-old female participant described it, "this illusion of having a better life for all of the family," meaning she believed it would be easy to have a better life in America. A forty-four-year-old female said in her interview, "We are the same- human beings." She discusses how immigrants are "unlucky people," who "don't decide where we're born." While positivity was described, difficulty was also addressed. Almost all of the participants also mentioned the difficulty they had coming to America and adjusting to the difference in culture, as well as the difficulty they had in Mexico. A forty-three-year-old female participant said: "I felt like a baby, that needed to learn everything." A fortyone-year-old female participant added to this idea with "It's way, way hard for people to have a better opportunity of life and be strong because family traditions- it's not the same." To address the difficulty in Mexico, many of the participants discussed not being able to find work in Mexico to support their families. A forty-two-year-old male participant said, "weeks, months, I can't find anything." Along with this, the same participant described how they "pay taxes" and are "responsible people," just as Americans do. Many of the interviewees discussed the process to America as "easy" until recently, when the process has become "hard," both because of new policies created to decrease immigration and because of the "cholos" and gangs that require immigrants to carry drugs across the border for them. Above all, as a thirty-year-old male immigrant said, "We're just all human, ya know?"

\section{Discussion}

Above all, the findings suggest the heavily negative rhetoric in the rally speeches contrasted the rhetoric used in the immigration stories of Mexican immigrants living in the central Indianapolis area. Previous literature has found the 
same overall tone of word choice towards immigrants that was discovered in my research within President Trump's speeches. The heavily negative rhetoric presented in President Trump's rally speeches has a tendency to characterize immigrants as criminals and could contribute to increased xenophobia. This finding aligns with the study conducted by Erika Quiñonez, in which xenophobia was also presented. Along with this, an "us versus them" environment, also discussed by Erika Quiñonez, is perpetuated, creating a separation between immigrants and American citizens (Quiñonez, 2018). President Trump's rhetoric lacks the humanity revealed in the immigration stories. One example that clearly illustrates this is when he discusses the topic of immigrants taking benefits from American citizens, which instills a sense of fear. This fear is also present in the anti-immigrant rhetoric analyzed by Kenzo Kawanabe in his study regarding Chinese immigrants (Kawanabe, 1996). History repeats itself, as the same stereotypes perpetuated by a fear of immigrants previously are still prevalent in the speeches analyzed from President Trump in more recent times. This fear is only furthered by the discussion of borders, perpetuating the separation that already exists between immigrants and American citizens. Descriptions such as the reference to immigrants as "animals" emphasize his wish to disassociate Mexican immigrants with the category of human beings (Trump, 2018a). This rhetoric matches that in the study done by Erika Quiñonez, with immigrants being portrayed in the same way: aliens and illegals (Quiñonez, 2018). There is an apparent ignorance of the situations Mexican immigrants have to endure in order to arrive in the United States, and dehumanization of them is prevalent throughout the speeches. As well as this, there is also a lack of understanding of the economic situation many immigrants face when they are living in America, only contributing to misunderstanding, ignorance, and xenophobia.

Contrastingly, the rhetoric used in the stories portrays immigrants in a more humanistic way, with words such as "hardworking" to describe them and looking for "more opportunities" to describe the motivation for coming to the United States. The immigrants' rhetoric connects American citizens and immigrants by merely addressing the fact that all people are just human beings, which contradicts the attitude from the rhetoric used in the speeches and President Trump's characterization of immigrants as "animals" (Trump, 2018a). The humanistic perspective conveyed in the immigrants' rhetoric is best described in the quote said by a thirty-year-old male participant, "We're just all human, ya know?" Furthermore, many of the immigrants solely came to America to be able to support their families, since the jobs in Mexico were scarce and low-paying. The results align with the study with Latino youth immigrants conducted by Linda K. Ko and Krista M. Perreira, which found the struggles the youth faced within their immigration journey (Ko \& Perreira, 2010). Their findings aligned with my results because they explicitly discuss the economic difficulties found within youth Latino immigrants (Ko \& Perreira, 2010). The same theme of economic difficulty when coming to America was also present within the rhetoric in the immigration stories from Mexican immigrants.

Another topic described by the immigrants was about being "clean," as a forty-two-year-old male participant described. This means they are not criminals and did not come for criminal intent. The topic is supported by previous literature and contrasts the description President Trump conveys, as one of the descriptors used by him is "criminals" (Trump, 2018a; Trump, 2018c; Trump, 2018c).

Within the broader context of the field, this study can aid in furthering the knowledge Americans have regarding the language used to describe immigrants and the reality of the situation. It can further the results of previous literature by indicating the differences between Mexican immigrants and President Trump. In a more significant scope, the rhetoric I analyzed in President Trump's speeches and how stark the contrast was when analyzed next to the immigrants' rhetoric contributes to a broader problem of the xenophobia present in American society and a fear of immigrants. These both lead to the negative rhetoric presented in the speeches. In turn, more humanistic and conscientious rhetoric should be used in order to describe Mexican immigrants, rather than the rhetoric found in President Trump's speeches. The immigration stories outline the struggles Mexican immigrants face and how starkly President Trump's rhetoric contrasts, which differs from the current research that defines either President Trump's rhetoric or immigrant rhetoric. 


\section{Limitations}

A possible limitation of this study involves the population that was interviewed. Because the participants all live in the same area, the study cannot be generalized to the entire population of Mexican immigrants. As well as this, because of the difficulties in finding participants, only a small number were interviewed, which could influence the results and could lead to a smaller variety of answers. Furthermore, some of the participants were part of the same family, and some heard the answers of other participants, which could have influenced their answers. Because the participants were asked to list words specifically that they would use to describe immigrants as people and the process of immigration, their answers could have been different had they been asked different questions. Another limitation is that this study is about Mexican immigrants, which I do not personally have experience with. I did not know where to find a Mexican community to interview, and I am not personally impacted by the experiences discussed in the interviews.

\section{Future Directions}

While this study specifically focused on Mexican immigrants in one area of one state of the United States, the findings could be used to influence other research with different variables. More research would need to be done with immigrants of differing origin or immigrants from different regions of the United States. Furthermore, research could also be conducted using different speeches done by either President Trump or other political figures. Because President Trump continues to give speeches discussing the theme of immigration, further research would need to be conducted in order to reveal how more recent speeches compare to immigration stories. In my study, an interesting theme that I encountered was the description of ICE workers with very positive characteristics, which could introduce another study to compare and analyze the rhetoric used to describe the ICE workers and the immigrants. Further study may also be conducted regarding different generations of immigrants or immigrants with differing experiences, such as young immigrants. Gaining a larger sample size of immigrants could also lead to the examination and analysis of different themes than those that were in my research.

\section{Conclusion}

Ultimately, rhetoric in the four rally speeches made by President Donald Trump and the rhetoric in the immigration stories of Mexican immigrants differs greatly and creates separate depictions and characterizations of immigrants and immigration as a whole. In the four rally speeches of President Donald Trump, the rhetoric used was heavily negative and characterized immigrants as criminals, aliens, and animals. The immigration stories collected from the interviews conducted contrast this. They instead emphasized immigrants' need to come to America for better lives, jobs, and opportunities in order to help their families. The immigrants also recognized the hardships they found in America. The findings from this study should be used in order to create an increasingly humanistic view of immigrants as people and to create awareness of the many types of political rhetoric involving immigration as a whole.

\section{References}

American Immigration Council. (2020, January 8). An Overview of U.S. Refugee Law and Policy. Retrieved from https://www.americanimmigrationcouncil.org/research/overview-us-refugee-law-and-policy

Barnes, B. J., Williams, E. A., \& Archer, S. A. (2010). Characteristics That Matter Most: Doctoral Students Perceptions of Positive and Negative Advisor Attributes. NACADA Journal, 30(1), 34-46. doi: 10.12930/0271-9517-

30.1.34. 
Chavez, L. R. (2013). Latino Threat: Constructing Immigrants, Citizens, and the Nation (2nd Edition). Stanford University Press.

Felter, C., \& Renwick, D. (2019, July 25). The U.S. Immigration Debate. Retrieved from https://www.cfr.org/backgrounder/us-immigration-debate-0

Fritze, J. (2019, August 21). Trump used words like 'invasion' and 'killer' to discuss immigrants at rallies 500 times: USA TODAY analysis. Retrieved from https:/www.usatoday.com/story/news/politics/elections/2019/08/08/trumpimmigrants-rhetoric-criticized-el-paso-dayton-shootings/1936742001/

Janesick, V. J. (2016). "Stretching" exercises for qualitative researchers. Los Angeles, CA: SAGE.

Kawanabe, K. S. (1996). American anti-immigrant rhetoric against asian pacific immigrants: The present repeats the past. Georgetown Immigration Law Journal, 10(4), 681-706.

Ko, L. K., \& Perreira, K. M. (2010). "It Turned My World Upside Down”: Latino Youths' Perspectives on Immigration. Journal of Adolescent Research, 25(3), 465-493. doi: 10.1177/07435588410361372.

Lazarus, E. (1883). Statue of Liberty [Inscription]. New York, New York.

Martin, P. (2014, January 14). Trends in Migration to the U.S. Retrieved from https://www.prb.org/us-migrationtrends/

Merriam Webster. (2020, February 14). Xenophobia. Retrieved from https://www.merriam-webster.com/dictionary/xenophobia

National Archives Foundation. (2015, November 20). Refugee Act of 1980. Retrieved from https://www.archivesfoundation.org/documents/refugee-act-1980/

Office of Refugee Resettlement. (2019, June 26). About. Retrieved from https://www.acf.hhs.gov/orr/about

Office of the Historian. (n.d.). The Immigration Act of 1924 (The Johnson-Reed Act). Retrieved

from https:/history.state.gov/milestones/1921-1936/immigration-act

Preceden. (n.d.). Waves of Immigration in America. Retrieved from

https://www.preceden.com/timelines/29989-waves-of-immigration-in-america

Quiñonez, Erika Sabrina. (2018). "(UN)WELCOME TO AMERICA: A CRITICAL DISCOURSE ANALYSIS OF ANTI-IMMIGRANT RHETORIC IN TRUMP'S SPEECHES AND CONSERVATIVE MAINSTREAM MEDIA" Electronic Theses, Projects, and Dissertations. 635. Retrieved from https://scholarworks.lib.csusb.edu/etd/635/

Relman, E. (2019, July 18). Republican voters have become more xenophobic as Trump has normalized racist rhetoric. Retrieved from https://www.businessinsider.com/republican-voters-have-become-more-xenophobic-undertrump-2019-7

Trump, D. J. (2018a, August). Evansville Rally. Evansville Rally. Evansville. Retrieved from https://www.courierpress.com/story/news/local/2018/09/04/heres-transcript-president-trumps-speech-evansville-rally/1191281002/ 
Trump, D. J. (2018b, May). Elkhart Rally. Elkhart Rally. Elkhart. Retrieved from https://factba.se/transcript/donaldtrump-speech-rally-elkhart-indiana-may-10-2018

Trump, D. J. (2018c, November). Fort Wayne Rally. Fort Wayne Rally. Fort Wayne. Retrieved from https://factba.se/transcript/donald-trump-speech-maga-rally-fort-wayne-in-november-5-2018

Trump, D. J. (2018d, November). Indianapolis Rally. Indianapolis Rally. Indianapolis. Retrieved from https://factba.se/transcript/donald-trump-speech-maga-rally-indianapolis-in-november-2-2018

U.S. Department of Homeland Security. (2020, January 6). Table 1. Persons Obtaining Lawful Permanent Resident Status: Fiscal Years 1820 to 2018. Retrieved from https://www.dhs.gov/immigration-statistics/yearbook/2018/table1

Waves of Immigration in America. (n.d.). Retrieved from https://www.preceden.com/timelines/29989-waves-ofimmigration-in-america 